\title{
Technical Note: Molecular characterization of aerosol-derived water soluble organic carbon using ultrahigh resolution electrospray ionization Fourier transform ion cyclotron resonance mass spectrometry
}

\author{
A. S. Wozniak ${ }^{1}$, J. E. Bauer ${ }^{1}$, R. L. Sleighter ${ }^{2}$, R. M. Dickhut ${ }^{1}$, and P. G. Hatcher ${ }^{2}$ \\ ${ }^{1}$ School of Marine Science, Virginia Institute of Marine Science, College of William and Mary, PO Box 1346, \\ Gloucester Point, VA 23062, USA \\ ${ }^{2}$ Department of Chemistry and Biochemistry, Old Dominion University, 4541 Hampton Blvd., Norfolk, VA 23529, USA
}

Received: 19 February 2008 - Published in Atmos. Chem. Phys. Discuss.: 4 April 2008

Revised: 15 July 2008 - Accepted: 11 August 2008 - Published: 2 September 2008

\begin{abstract}
Despite the acknowledged relevance of aerosolderived water-soluble organic carbon (WSOC) to climate and biogeochemical cycling, characterization of aerosol WSOC has been limited. Electrospray ionization Fourier transform ion cyclotron resonance mass spectrometry (ESI FT-ICR MS) was utilized in this study to provide detailed molecular level characterization of the high molecular weight (HMW; $\mathrm{m} / \mathrm{z}>223$ ) component of aerosol-derived WSOC collected from rural sites in Virginia and New York, USA. More than 3000 peaks were detected by ESI FT-ICR MS within a m/z range of 223-600 for each sample. Approximately 86\% (Virginia) and $78 \%$ (New York) of these peaks were assigned molecular formulas using only carbon $(\mathrm{C})$, hydrogen $(\mathrm{H})$, oxygen $(\mathrm{O})$, nitrogen $(\mathrm{N})$, and sulfur $(\mathrm{S})$ as elemental constituents. $\mathrm{H} / \mathrm{C}$ and $\mathrm{O} / \mathrm{C}$ molar ratios were plotted on van Krevelen diagrams and indicated a strong contribution of lignin-like and lipid-like compounds to the aerosol-derived WSOC samples. Approximately $1-4 \%$ of the peaks in the aerosol-derived WSOC mass spectra were classified as black carbon (BC) on the basis of double bond equivalents calculated from the assigned molecular formulas. In addition, several high-magnitude peaks in the mass spectra of samples from both sites corresponded to molecular formulas proposed in previous secondary organic aerosol (SOA) laboratory investigations indicating that SOAs are important constituents of the WSOC. Overall, ESI FT-ICR MS provides a level of resolution adequate for detailed compositional and source information of the HMW constituents of aerosolderived WSOC.
\end{abstract}

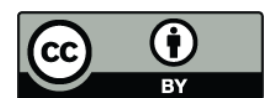

Correspondence to: A. S. Wozniak (wozniak@vims.edu)

\section{Introduction}

The importance of atmospheric aerosols to several areas of environmental study has been well-documented. Natural and anthropogenically-derived aerosols alter Earth's radiative heat balance, and therefore climate, through scattering and absorption of solar radiation and reduction of outgoing longwave terrestrial radiation (e.g. Ramanathan et al., 2001; Satheesh and Moorthy, 2005; Highwood and Kinnersley, 2006). Elevated concentrations of aerosols (specifically hygroscopic aerosols) due to human activities increase the number of cloud condensation nuclei (CCN) that act as seed for cloud droplets. Because of the limited amount of atmospheric water vapor available for cloud formation, an increase in $\mathrm{CCN}$ number may reduce the average size of CCN such that it may limit precipitation and thereby increase the lifetime of clouds, thus serving as an indirect positive feedback on climate change (Toon, 2000; Ramanathan et al., 2001; Lohmann and Feichter, 2005).

In addition to the general role of aerosols in climate, fossil fuel and biomass combustion produce anthropogenicallyderived aerosols that are known to impair visibility (Charlson, 1969; Jacobson et al., 2000), contribute to ecosystemlevel problems via rain acidification (Likens and Bormann, 1974; Driscoll et al., 2001 and references therein) and the transport and deposition of persistent organic pollutants (Dickhut et al., 2000; Galiulin et al., 2002; Jurado et al., 2004), and cause cardiovascular and respiratory problems in humans (Davidson et al., 2005; Highwood and Kinnersley, 2006). Furthermore, atmospherically-derived materials in aerosol form are potentially important in a biogeochemical context. For example, recent studies estimate that $30-90 \mathrm{Tg} \mathrm{yr}^{-1}$ of aerosol-derived organic carbon (OC; Koch,

Published by Copernicus Publications on behalf of the European Geosciences Union. 
2001; Bond et al., 2004) and 8-24 $\mathrm{Tg} \mathrm{yr}^{-1}$ black carbon (BC; Penner et al., 1993; Bond et al., 2004) are deposited globally. These fluxes are potentially significant in the context of carbon cycling and elemental budgets at the atmosphere-landwater interfaces, especially in areas where industrial sources are significant. Given the potential quantitative importance of aerosol OC to different terrestrial and aquatic systems, molecular level characterization of aerosols is critical for both tracing the sources of aerosol OC and assessing its transformations before and after deposition.

Aerosols tend to be highly carbonaceous in nature with OC often comprising $10-30 \%$ of total aerosol mass (e.g. Wolff et al., 1986; Jacobson et al., 2000; Tanner et al., 2004; Liu et al., 2005). In addition, as much as $20-70 \%$ of aerosol OC has been found to be water-soluble (WSOC; Krivacsy et al., 2001; Kleefeld et al., 2002; Yang et al., 2004; Decesari et al., 2007). As noted above, only hygroscopic aerosols can act as CCN, making WSOC an important indirect climate agent (Saxena and Hildemann 1996; Fuzzi et al., 2001; Satheesh and Moorthy, 2005). Aerosol WSOC is also likely to be the fraction of aerosol OC that is most rapidly transported along with surface and ground waters through watersheds to lakes, rivers, and estuaries on timescales relevant to carbon biogeochemical cycling.

Despite the potential importance of aerosol WSOC, detailed molecular characterization of this component of aerosols has thus far been limited. Attempts to characterize WSOC at the molecular level using gas chromatographymass spectrometry (GC-MS; Mayol-Bracero et al., 2002; Wang et al., 2006) and a combination of ion chromatography and high performance liquid chromatography (HPLC; Yang et al., 2004) characterized less than $10 \%$ and $20 \%$ of WSOC, respectively. Aerosol WSOC has been characterized at the functional group level using HPLC (Mayol-Bracero et al., 2002), ${ }^{1} \mathrm{H}$ (Decesari et al., 2000) and cross-polarizationmagic angle spinning ${ }^{13} \mathrm{C}$ (Duarte et al., 2005; Sannigrahi et al., 2006) nuclear magnetic resonance (NMR) spectroscopy, Fourier transform infrared spectroscopy (Duarte et al., 2005), and size exclusion chromatography (Sullivan and Weber, 2006). Both the molecular (Mayol-Bracero et al., 2002; Yang et al., 2004; Yu et al., 2005; Wang et al., 2006) and the functional group level characterization efforts (Decesari et al., 2000; Mayol-Bracero et al., 2002; Duarte et al., 2005; Sannigrahi et al., 2006; Sullivan and Weber, 2006) have found mono- and di-carboxylic acids as well as polyconjugated acids (sometimes described as humic-like substances, HULIS) to be the most prevalent compounds in WSOC, followed by neutral compounds such as sugars.

The high concentrations of acidic species in aerosolderived WSOC is likely indicative of the presence of secondary organic aerosols (SOA) formed from the oxidation of naturally and anthropogenically emitted volatile organic carbon (VOC) precursors (Jaoui et al., 2005; Kanakidou et al., 2005; Sullivan and Weber, 2006). To date, however, much of the work identifying SOA compounds has relied on experimental laboratory investigations (e.g. Forstner et al., 1997; Jang and Kamens, 2001; Kanakidou et al., 2005; Heaton et al., 2007), and very few SOA compounds have been identified in ambient aerosol samples (Edney et al., 2003; Tolocka et al., 2004; Jaoui et al., 2005). Comprehensive molecular characterization of WSOC derived from ambient aerosol material will therefore complement studies of SOA formation processes, atmosphere-land-water biogeochemical fluxes, and climate-related effects of WSOC.

Electrospray ionization coupled to Fourier transform ion cyclotron resonance mass spectrometry (ESI FT-ICR MS) provides detailed molecular characterization of organic matter due to its extremely high resolution and mass accuracy (Marshall et al., 1998; Kujawinski et al., 2002a; Sleighter and Hatcher, 2007). ESI is a "soft" ionization technique that produces minimal fragmentation of the analytes, thus allowing for detection of intact molecules (Stenson et al., 2002) and is a particularly effective technique for ionizing polar, hydrophilic molecules (Gaskell, 1997; Kujawinski, 2002; Sleighter and Hatcher, 2007) similar to those found in aerosol WSOC. FT-ICR MS provides ultrahigh mass resolving powers $(>300000)$ and mass accuracy $(<1 \mathrm{ppm})$, enabling the identification of many distinct peaks at a given nominal mass (Marshall et al., 1998; Kujawinski et al., 2002a; Sleighter and Hatcher, 2007). These features of FT-ICR MS allow for molecular formulas to be assigned to the peaks thereby providing valuable molecular level information. However, it must also be noted that because FT-ICR MS does not provide structural information, these molecular formulas may represent any of several structural isomers.

Recently, ESI FT-ICR MS has been used to successfully characterize complex mixtures of natural organic matter including fulvic and humic acids extracted from rivers (Kujawinski et al., 2002a; Stenson et al., 2003; Kujawinski et al., 2004), soils (Kujawinski et al., 2002a; Kramer et al., 2004; Hockaday et al., 2006), peat (Kramer et al., 2004), and degraded wood (Kujawinski et al., 2002a; Kim et al., 2003a; Kramer et al., 2004). In addition to these organic matter extracts, the technique has also been used successfully for characterizing bulk dissolved organic matter (DOM) from riverine (Kim et al., 2003a, b; Stenson et al., 2003; Kim et al., 2004; Sleighter and Hatcher 2008) and marine waters (Koch et al., 2005; Tremblay et al., 2007), ice cores (Grannas et al., 2006), mangrove sediment porewaters (Koch et al., 2005; Tremblay et al., 2007; Sleighter and Hatcher 2008), and soils (Hockaday et al., 2006). Amongst the key findings in recent ESI FT-ICR MS studies has been the detection of potential BC compounds in soil humic acids (Kramer et al., 2004) and riverine (Kim et al., 2003b; Kim et al., 2004), ice core (Grannas et al., 2006), and soil DOM (Hockaday et al., 2006). Grannas et al. (2006) showed that BC can be identified in melt water from ice cores, possibly reflecting historically-deposited atmospheric precipitation in snowaccumulating regions of the world. With biomass and fossil fuel combustion thought to be the dominant sources of BC, 
ESI FT-ICR MS analysis of aerosol WSOC may be useful for detecting the mobile, water-soluble component of $\mathrm{BC}$ present in aerosols.

In the present study, we demonstrate the utility of ESI FTICR MS for qualitative characterization of aerosol-derived WSOC. The mass spectral data is used to derive novel information on the general molecular composition of aerosolderived material collected in two different watersheds of the northeastern United States. Although ESI FT-ICR MS is not a quantitative technique, the detailed molecular information that it provides allows for novel insights on the character and potential sources of aerosol WSOC.

\section{Experimental section}

\subsection{Sample collection and field methods}

For the ESI FT-ICR MS analyses, two-day integrated high-volume aerosol samples $\left(>4000 \mathrm{~m}^{3}\right)$ were collected during 16-18 August 2006 at the Institute of Ecosystem Studies Environmental Monitoring Station in Millbrook, NY (http://www.ecostudies.org/emp_purp.html) and 7-9 November 2006 at the National Atmospheric Deposition Program (NADP) site (VA98) located in Gloucester County, VA (http://nadp.sws.uiuc.edu/sites/siteinfo.asp?net= NTN\&id=VA98) using total suspended particulate (TSP) air samplers (Model GS2310, ThermoAndersen, Smyrna, GA). Both sites are located in rural environments and are more than $30 \mathrm{~km}$ from major industrial emissions. Air was drawn through pre-ashed $\left(3 \mathrm{~h}, 525^{\circ} \mathrm{C}\right)$ and pre-weighed highpurity quartz microfibre filters $(20.3 \mathrm{~cm} \times 25.4 \mathrm{~cm}$, nominal pore size $0.6 \mu \mathrm{m}$; Whatman QM-A grade) for collection of aerosol particles. Following collection, aerosol filter samples were transferred to pre-ashed $\left(3 \mathrm{~h}, 525^{\circ} \mathrm{C}\right)$ aluminum foil pouches and stored in the dark in a carefully cleaned air-tight polycarbonate desiccator until analysis. Samples for radiocarbon analyses of the aerosol WSOC were collected from the NY sampling station on three occasions in August of 2006 (8/16-17, 8/18-20, 8/20-21) following the same procedures.

2.2 Aerosol mass, OC, BC, WSOC, and $\mathrm{WSO}^{14} \mathrm{C}$ measurements

Filters were weighed pre- and post-sampling to obtain a measure of the total aerosol mass. Replicate core plug subsamples were taken from the 24 -h air filters (using $2.85 \mathrm{~cm}^{2} \mathrm{di}$ ameter stainless steel cork borers) for OC, BC, and WSOC determination. For OC determination, samples were dried overnight at $60^{\circ} \mathrm{C}$, acidified with $1 \mathrm{M} \mathrm{HCl}$ to remove inorganic carbon species and again dried overnight at $60^{\circ} \mathrm{C}$. Triplicate acidified and non-acidified samples were placed in $5^{\times} 9 \mathrm{~mm}$ tin cups and combusted at $850^{\circ} \mathrm{C}$ in the presence of $\mathrm{O}_{2}$. Concentrations of $\mathrm{OC}$ were determined using a $\mathrm{CE}$ Elantech Flash EA 1112 NC Soil analyzer. Sample response areas were calibrated to a standard curve using a sulfanilamide standard.

BC was quantified by combusting pre-acidified $(1 \mathrm{M} \mathrm{HCl})$ triplicate core plug subsamples in a muffle furnace at $375^{\circ} \mathrm{C}$ in the presence of high purity air for $24 \mathrm{~h}$ (CTO-375; Gustafsson et al. 1997). The carbon remaining on the filters after combustion was assumed to be $\mathrm{BC}$ and was measured using a CE Elantech Flash EA 1112 NC Soil Analyzer as for bulk aerosol OC above. Diesel particulate matter from the exhaust of an industrial forklift (National Institute of Standards and Technology standard reference material 2975; SRM-2975) was used as a positive BC standard, and SRM-2975 BC measurements agreed with published values (Elmquist et al., 2006).

For aerosol WSOC concentration measurements, individual cork borer plugs were taken from the filters and placed in pre-baked scintillation vials. High-purity water was added to the plugs, and the samples were sonicated for $30 \mathrm{~min}$ to allow for WSOC desorption. The extract was then filtered through pre-combusted $25-\mathrm{mm} \mathrm{GF} / \mathrm{F}(0.7 \mu \mathrm{m}$ nominal pore size), and the filtrate was collected and measured for DOC on a Shimadzu model TOC-5000A analyzer.

WSOC was also isolated for isotopic $\left(\Delta^{14} \mathrm{C}\right)$ characterization. Aerosol material was placed in $150 \mathrm{ml}$ of high purity Nanopure water and soaked to allow for WSOC desorption then filtered through pre-baked $0.7 \mu \mathrm{m}$ GF/F filters. The WSOC samples $(\sim 125 \mathrm{ml})$ were acidified to $\mathrm{pH} 2.5$ with phosphoric acid and sparged with pure helium gas for $10 \mathrm{~min}$ to remove inorganic carbon. Samples were then saturated with pure oxygen gas and irradiated for $3 \mathrm{~h}$ with a mediumpressure, high-energy $(2400 \mathrm{~W}) \mathrm{UV}$ lamp (Raymond and Bauer, 2001). The carbon dioxide generated from the WSOC oxidation was purified and collected on a vacuum extraction line for subsequent determination of $\Delta^{14} \mathrm{C}$. The samples were then submitted to the University of Arizona NSF Accelerator Mass Spectrometry laboratory where the carbon dioxide was converted to graphite and processed for isotopic analysis.

\subsection{Aerosol-derived $\mathrm{WSOC}_{18}$ extraction procedure}

Approximately half of each aerosol filter was cut into strips using solvent-cleaned (hexane, acetone, and methanol) razor blades and placed in pre-combusted $\left(500^{\circ} \mathrm{C}\right)$ and solventcleaned 1-L glass beakers. Approximately $200 \mathrm{~mL}$ of LCMS grade water (Fisher Scientific) was added to the filter strips, and samples were sonicated for $30 \mathrm{~min}$ to extract the WSOC from the filters. The extracted organic matter was then isolated and concentrated from the WSOC filtrates using $\mathrm{C}_{18}$ solid phase extraction disks (3M, Empore) following previously established protocols (Kim et al., 2003a). The $\mathrm{C}_{18}$ disks were activated using LC-MS grade water and methanol (Fisher Scientific), and each WSOC sample was acidified to a pH of 2 with $10 \mathrm{M} \mathrm{HCl}$ before passing through the disk. The sorbed material was rinsed with LC-MS grade water 
before eluting it off the disk with 4-6 mL of LC-MS grade methanol. Due to the qualitative nature of these studies, the recovery from the $\mathrm{C}_{18}$ disk was not measured for these specific samples, however, previous studies have shown that approximately $42-60 \%$ of freshwater dissolved organic matter is recovered by this technique (Louchouarn et al., 2000; Kim et al., 2003a). Methanol has been found to induce self-esterification in humic and fulvic acids (McIntyre and McRae, 2005). However, the self-esterification phenomenon is more pronounced in positive ion mode than in negative ion mode and increases with the amount of time the sample remains in methanol (McIntyre and McRae, 2005). Because our samples were run in negative ion mode within $2 \mathrm{~h}$ of elution with methanol, self-esterification in our samples is likely to be minimal.

\section{Analytical methods}

Previous studies have determined that water/methanol mixtures yield higher quality mass spectra (Kujawinski et al., $2002 \mathrm{~b}$; Rostad and Leenheer, 2004), therefore, the $\mathrm{C}_{18}$ extracts of aerosol WSOC were diluted by $25 \%$ with LCMS grade water. In order to increase the ionization efficiency, a small amount of ammonium hydroxide $(<0.1 \%$ total volume) was added immediately prior to ESI, raising the $\mathrm{pH}$ of the sample to approximately 8 . Within two hours of WSOC $\mathrm{C}_{18}$-extraction and elution, samples were continuously infused into the Apollo II ESI ion source of a Bruker Daltonics 12 Tesla Apex Qe FT-ICR MS, housed at the College of Sciences Major Instrumentation Cluster (COSMIC) at Old Dominion University (http://www.sci.odu. edu/sci/cosmic/index.shtml). Samples were introduced by a syringe pump providing an infusion rate of $120 \mu \mathrm{L} \mathrm{hr}^{-1}$. All samples were analyzed in negative ion mode, and electrospray voltages were optimized for each sample. Previous studies have shown that the negative ion mode avoids the complications associated with the positive ion mode in which alkali metal adducts, mainly $\mathrm{Na}^{+}$, are observed along with protonated ions (Brown and Rice, 2000; Rostad and Leenheer, 2004). Ions were accumulated in a hexapole for $1.0 \mathrm{~s}$ before being transferred to the ICR cell. Exactly 300 transients, collected with a 4 MWord time domain, were added, giving about a $30 \mathrm{~min}$ total run time for each sample. The summed free induction decay (FID) signal was zero-filled once and Sine-Bell apodized prior to fast Fourier transformation and magnitude calculation using the Bruker Daltonics Data Analysis software.

3.1 Mass calibration and molecular formula assignments of aerosol WSOC

Prior to data analysis, all samples were externally calibrated with an arginine cluster standard and internally calibrated with fatty acids naturally present within the sample (Sleighter et al., 2008). The ultrahigh resolving power of $12 \mathrm{TFT}$ ICR MS is capable of separating $\mathrm{m} / \mathrm{z}$ values to a mass accuracy of less than $1 \mathrm{ppm}$. Isotopic peaks are observed in the mass spectra at $1.00335 \mathrm{~m} / \mathrm{z}$ units (the mass of a neutron) higher than the parent peak indicating that the peaks are singly charged. This is the case for the entire mass range, indicating that all peaks are singly charged $(\mathrm{z}=1)$, which is similar to previous findings for DOM (Kujawinski et al., 2002; Stenson et al., 2002; Kim et al., 2003b). Since all the peaks are singly charged, $\mathrm{m} / \mathrm{z}$ is assumed to be equivalent to molecular weight, and molecular formula information can be obtained. A molecular formula calculator developed at the National High Magnetic Field Laboratory in Tallahassee, FL (Molecular Formula Calc v.1.0 ONHMFL, 1998; http://www.magnet.fsu.edu/) generated empirical formula matches using carbon $(\mathrm{C})$, hydrogen $(\mathrm{H})$, oxygen $(\mathrm{O})$, nitrogen $(\mathrm{N})$, sulfur $(\mathrm{S})$, and phosphorus $(\mathrm{P})$. Only $\mathrm{m} / \mathrm{z}$ values with a signal-to-noise above 4 were inserted into the molecular formula calculator. In the vast majority of cases, the exact mass of each assigned formula agreed with the $\mathrm{m} / \mathrm{z}$ value to within less than $0.5 \mathrm{ppm}$.

\subsubsection{Data processing}

Molecular formulas generated by the molecular formula calculator were pre-processed using a MatLab file (The MathWorks Inc., Natick, MA) developed by our group that employed several conservative rules similar to those used in previous studies (Koch et al., 2005; Kujawinski and Behn 2006) in order to eliminate compounds not likely to be observed in nature. The pre-processing file eliminated all molecular formulas in which: $\mathrm{O} / \mathrm{C} \geq 1.2, \mathrm{H} / \mathrm{C} \geq 2.25, \mathrm{H} / \mathrm{C} \leq 0.3, \mathrm{~N} / \mathrm{C} \geq 0.5$, $\mathrm{S} / \mathrm{C} \geq 0.2, \mathrm{P} / \mathrm{C} \geq 0.1,(\mathrm{~S}+\mathrm{P}) / \mathrm{C} \geq 0.2$, and $\mathrm{DBE}$ (double bond equivalents) $<0$, where DBE is calculated as follows:

$\mathrm{DBE}=(2 c+2-h+n+p) / 2$

for any formula $\mathrm{C}_{c} \mathrm{H}_{h} \mathrm{~N}_{n} \mathrm{O}_{o} \mathrm{~S}_{s} \mathrm{P}_{p}$. DBE indicates the number of rings and double bonds in a molecule and is a measure of the degree of unsaturation in a given compound (Hockaday et al., 2006).

In addition to these rules, the MatLab file searched for and eliminated peaks detected by the FT-ICR MS that were 1.003 mass units greater than another detected peak, under the assumption that the two peaks represent the same compound, with the peak at the higher $\mathrm{m} / \mathrm{z}$ having a ${ }^{13} \mathrm{C}$ in place of a ${ }^{12} \mathrm{C}$. Following pre-processing, molecular formulas were assigned following the "formula extension" approach described by Kujawinski and Behn (2006). Phosphorous is typically not a quantitatively significant component of atmospheric materials (Chen et al., 2002; Grimshaw and Dolske, 2002; Baker et al., 2006); therefore all molecular formulas containing phosphorous were eliminated for ease of processing. Additionally, by analyzing solvent blanks, peaks below $\mathrm{m} / \mathrm{z} 223$ were determined to be high frequency noise and were not assigned molecular formulas. Compounds at $\mathrm{m} / \mathrm{z}$ below 223 are likely 
Table 1. Aerosol TP, OC, BC and WSOC concentrations and $\mathrm{OC} / \mathrm{TP}, \mathrm{BC} / \mathrm{OC}$, and WSOC/OC fractions for VA and NY samples.

\begin{tabular}{|c|c|c|}
\hline & NY & VA \\
\hline $\mathrm{TP}\left(\mu \mathrm{g} \mathrm{m}^{-3}\right)$ & 14.3 & 6.30 \\
\hline $\mathrm{OC}\left(\mu \mathrm{g} \mathrm{m}^{-3}\right)^{a}$ & $3.33 \pm 0.128$ & $1.25 \pm 0.084$ \\
\hline $\mathrm{BC}\left(\mu \mathrm{g} \mathrm{m}^{-3}\right)^{a}$ & $0.168 \pm 0.021$ & $0.022 \pm 0.002$ \\
\hline $\operatorname{WSOC}\left(\mu \mathrm{g} \mathrm{m}^{-3}\right)^{a}$ & $1.07 \pm 0.017$ & $0.373 \pm 0.010$ \\
\hline$(\mathrm{OC} / \mathrm{TP})^{a}$ & $0.232 \pm 0.009$ & $0.199 \pm 0.013$ \\
\hline$(\mathrm{BC} / \mathrm{OC})^{b}$ & $0.050 \pm 0.007$ & $0.018 \pm 0.002$ \\
\hline$(\mathrm{WSOC} / \mathrm{OC})^{b}$ & $0.320 \pm 0.013$ & $0.298 \pm 0.021$ \\
\hline
\end{tabular}

${ }^{a}$ Errors are reported as standard deviations of analytical errors from triplicate analyses.

${ }^{b}$ Errors are reported as standard deviations of propagated analytical errors from triplicate analyses.

present in these samples but are not detected by FT-ICR MS. Quadrupole efficiency is lower for $\mathrm{m} / \mathrm{z}<223$, and therefore, the magnitude and presence of these components are discriminated against in the quadrupole. Furthermore, ions with high ion cyclotron frequencies (the low mass molecules) are more difficult to detect because their orbit within the ICR cell must be increased to an amplitude that is sufficient to generate a strong enough image current on the detector plates.

\section{Results and discussion}

\subsection{Aerosol OC, BC, and WSOC}

The total particulate (TP) concentrations in the New York aerosol (14.3 $\mathrm{\mu g} \mathrm{m}^{-3}$; Table 1) were more than twice that of the Virginia aerosol $\left(6.30 \mu \mathrm{g} \mathrm{m}^{-3}\right.$; Table 1). OC accounted for nearly $20 \%$ and $23 \%$ of the TP mass in the Virginia and New York aerosol samples, respectively (Table 1). Concentrations of TP and OC for these samples were within the range of values reported for other rural and background sites (Table 1; Krivacsy et al., 2001 and references therein; Tanner et al., 2004; Liu et al., 2005). WSOC accounted for approximately $30 \%$ of the OC at both sites, a value near the low end of published WSOC/OC values (Table 1; 20-70\%; Krivacsy et al., 2001; Kleefeld et al., 2002; Yang et al., 2004; Decesari et al., 2007). BC was a minor component of the bulk aerosol carbonaceous material, accounting for only $\sim 2 \%$ of the OC in the Virginia sample and $\sim 5 \%$ of the OC in the New York sample (Table 1). Zencak et al. (2007) measured similar low BC concentrations in aerosols at two sites in Sweden using the same method employed here (CTO-375; Gustafsson et al., 1997). The CTO-375 method measures only highly condensed soot-BC, and a recent interlaboratory BC methods comparison of several reference materials consistently showed lower levels of BC measured by this method compared to chemical and thermal-optical methods (Hammes et
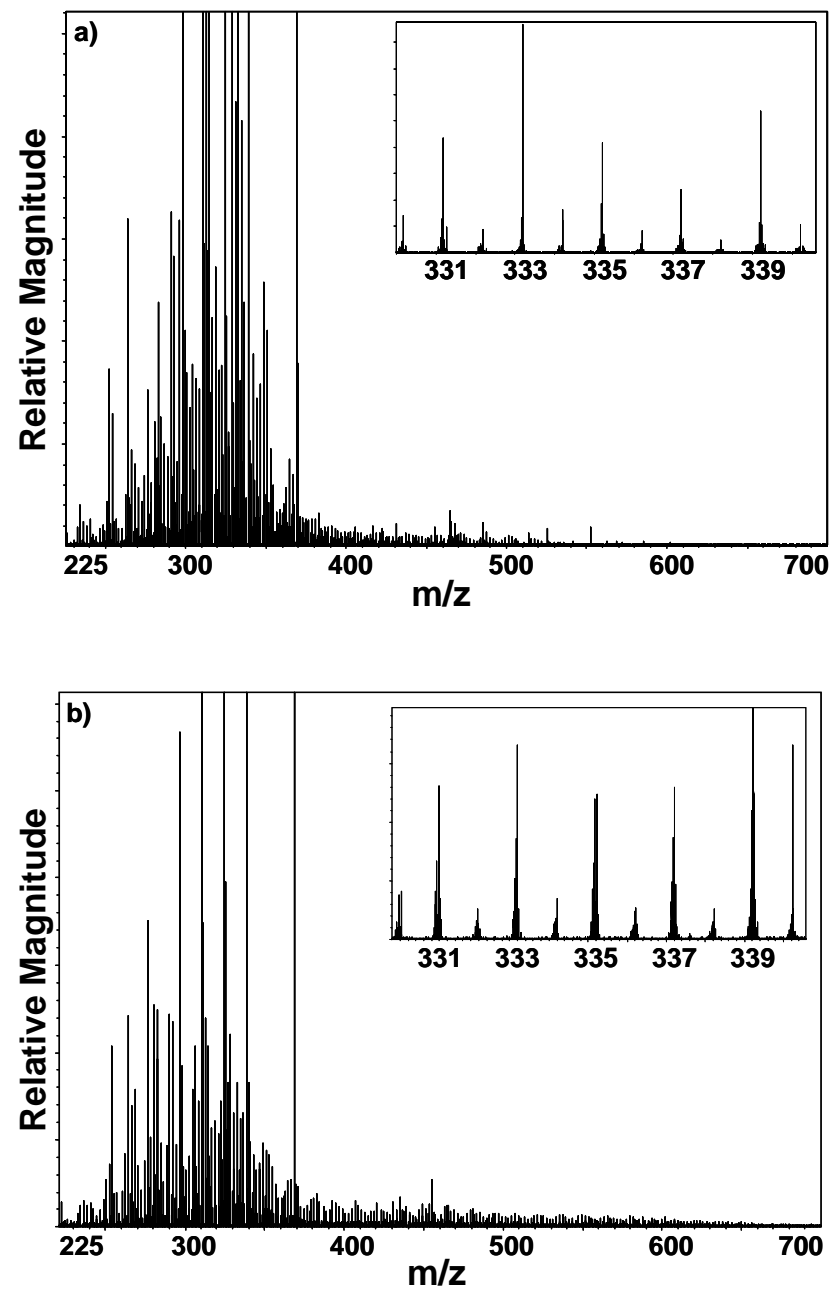

Fig. 1. ESI FT-ICR mass spectra for aerosol WSOC samples collected in a) August 2006 in New York and b) November 2006 in Virginia, USA. Insets highlight the m/z 330 - 340 region showing characteristic peak distributions and that the peaks are singly charged.

al., 2007). Thus, these BC estimates are likely conservative estimates of the total aerosol $\mathrm{BC}$ content in these samples.

\subsection{Mass spectra}

ESI FT-ICR mass spectra for aerosol-derived WSOC samples from both locations showed over 3000 peaks and remarkably similar patterns in peak distribution. The greatest peak magnitudes were located between $\mathrm{m} / \mathrm{z} 250$ and 375 , and considerably smaller magnitude peak clusters were centered around m/z 450 and 550 (Fig. 1a, b). Peak magnitude is not indicative of a compound's concentration in a sample due to inherent biases of $\mathrm{C}_{18}$ extractions and electrospray ionization efficiencies (Hockaday et al., 2006). In addition, only two samples were investigated here, so further work is required to determine whether this is a characteristic 


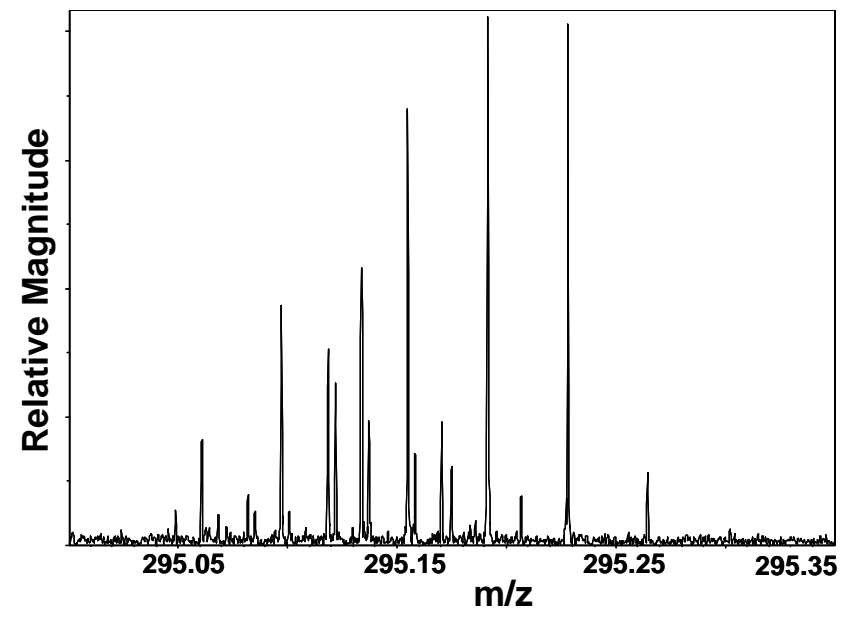

Fig. 2. Expanded ESI FT-ICR mass spectrum region from Figure 1a at $\mathrm{m} / \mathrm{z} 295$ for the aerosol WSOC sample from New York in August of 2006.

molecular weight distribution of aerosol WSOC. Nonetheless, the similarity between the spectra is striking given the differences in dates and locations of sampling (August 2006, Millbrook, NY vs. November 2006, Harcum, VA) and may suggest inherent similarities of aerosol WSOC from rural or background sites. Dismal Swamp DOM (Sleighter and Hatcher, 2007) and Mount Rainier humic acid (Kujawinski et al., 2002a) also showed strongest peak magnitudes at $\mathrm{m} / \mathrm{z} 250$ to 375 in their ESI FT-ICR spectra, indicating similar molecular weight distributions between these three different sample types.

Spectral details for both samples (see insets for Fig. 1a, b) show that $\mathrm{m} / \mathrm{z} 330-340$ demonstrated a typical pattern of several peaks at low mass defects (mass defect is the distance a peak is displaced from the exact nominal mass) from a given odd-numbered nominal mass, and fewer, less intense peaks at even-numbered nominal masses (e.g. Kujawinski, 2002; Kim et al., 2004; Sleighter and Hatcher, 2007). As stated in Sect. 3.1 above and demonstrated in the insets of Fig. 1a, b, the peaks detected are all singly charged. Evennumbered nominal mass peaks are indicative of either ${ }^{13} \mathrm{C}$ isotopic peaks (observed at a mass difference of $1.003 \mathrm{~m} / \mathrm{z}$ greater than its ${ }^{12} \mathrm{C}$ counterpart) or $\mathrm{N}$-containing compounds with an odd number of $\mathrm{N}$ (Koch et al., 2005). N-containing compounds are preferentially discriminated against in $\mathrm{C}_{18}$ extraction methods because the polar nature of organic nitrogen precludes its quantitative retention on the hydrophobic $\mathrm{C}_{18}$ disk (Benner 2002; Koch et al., 2005); therefore, any Ncontaining compounds present in the WSOC samples would likely be present at relatively smaller peak magnitudes.
Figure 2 illustrates both the ultrahigh mass resolving power of FT-ICR MS and the heterogeneous nature of aerosol WSOC. Similar to other mixtures of natural organic matter (e.g. Kim et al., 2004; Kujawinski et al., 2004; Koch et al., 2005), aerosol WSOC in this study was found to be highly complex, containing more than 3000 peaks in a single sample (Fig. 1) and 10-20 peaks at any given nominal mass (Fig. 2). Most often, there is less than $0.0001 \mathrm{Da}$ separating any two distinct peaks (Fig. 2). Only instrumentation with mass-resolving powers as high as FT-ICR MS can obtain the separation necessary to resolve peaks at such small mass differences.

\subsection{Formula assignments}

Using a formula extension approach similar to that described by Kujawinski and Behn (2006), 86\% and 78\% of the peaks identified in the mass spectra for the Virginia and New York aerosol WSOC samples, respectively, were assigned molecular formulas. Most of the assigned molecular formulas contained only $\mathrm{C}, \mathrm{H}$, and $\mathrm{O}$ (Table 2). The New York aerosol WSOC had a higher percentage of molecular formulas containing $\mathrm{C}, \mathrm{H}, \mathrm{O}$, and $\mathrm{S}$ (26\% versus $17 \%$; Table 2 ) than the Virginia sample. In contrast, molecular formulas containing $\mathrm{C}, \mathrm{H}, \mathrm{O}$, and $\mathrm{N}$ accounted for $26 \%$ of those identified in the Virginia sample vs. only $16 \%$ in the New York sample (Table 2). While ESI FT-ICR mass spectra do not provide a quantitative estimate of concentrations, the New York and Virginia WSOC samples were analyzed on the same instrument using the same protocols and methods, and therefore the resulting spectra reflect the same inherent biases. Because of the similar sample processing, we may calculate and compare magnitude-weighted percent contributions for various compound groups (e.g. C-H-O, C-H-O-N, C-H-O-S, C-H-O-N-S; Table 2; Sleighter and Hatcher, 2008). These magnitude-weighted percent contributions support a greater contribution of S-containing compounds to the New York aerosol WSOC sample than to the Virginia WSOC sample, and a greater contribution of $\mathrm{N}$-containing compounds to the Virginia aerosol WSOC sample compared to that from the New York sample.

\section{4 van Krevelen analysis}

The assigned molecular formulas of aerosol WSOC are represented in van Krevelen diagrams (Fig. 3a, b) which plot molar ratios $(\mathrm{H} / \mathrm{C}$ vs. $\mathrm{O} / \mathrm{C})$ of molecular formulas against each other. Also plotted are representative molar ratios for major classes of natural and anthropogenic organic compounds (i.e., ovals in Fig. 3a, b) in order to provide potential source information for the aerosol WSOC samples (see also Kim et al., 2003b; Kujawinski et al., 2004; Sleighter and Hatcher, 2007). In addition to major compound classes frequently used to apportion sources of dissolved organic matter (Kim et al., 2003b; Kujawinski et al., 2004; Sleighter and 
Table 2. Percent occurrence of formula groups and magnitudeweighted percent contribution of formula groups to all peaks assigned molecular formulas in the mass spectra. Formulas are grouped based on their elemental constituents (see text for greater detail).

\begin{tabular}{lcccc}
\hline & \multicolumn{2}{c}{ Percent Occurrence } & \multicolumn{2}{c}{$\begin{array}{l}\text { Magnitude-Weighted } \\
\text { Percent Contribution }\end{array}$} \\
\hline Elemental Constituents & VA & NY & VA & NY \\
\hline C, H, O & 57 & 58 & 77 & 75 \\
C, H, O, N & 26 & 16 & 12 & 6 \\
C, H, O, S & 17 & 26 & 11 & 19 \\
C, H, O, N, S & $<1$ & $<1$ & $<1$ & $<1$ \\
\hline
\end{tabular}

Hatcher, 2007), SOAs and mono- and di-carboxylic acids, compounds frequently associated with WSOC, are included to provide additional likely sources to aerosols (Fig. 3a, b; Yang et al., 2004; Yu et al., 2005; Sullivan and Weber, 2006; Wang et al., 2006).

The majority of aerosol WSOC molecular formulas identified by ESI FT-ICR MS in this study had molar H/C and $\mathrm{O} / \mathrm{C}$ ratios similar to lipids, lignin, mono- and di-carboxylic acids, and SOAs (Fig. 3a, b). Molecular formulas with molar ratios reflective of protein sources were also abundant; however, the majority of these compounds do not contain nitrogen, a component of every amino acid, indicating that proteins are an unlikely source for these particular compounds in the present study. Few molecular formulas plotted within the regions characteristic of tannins, cellulose, and condensed hydrocarbons (Fig. 3a, b) suggesting that these groups are also not major contributors to aerosol WSOC. Many of the molecular formulas plotted outside any of the source signature regions and had low $\mathrm{O} / \mathrm{C}(\sim 0$ to 0.2$)$ and $\mathrm{H} / \mathrm{C}(\sim 1$ to 1.5) ratios indicating one or more unknown sources. There are currently very few reports of SOA H/C and O/C molar ratios (Reinhardt et al., 2007; Altieri et al., 2008), however, with further investigation the region representing SOA may prove to be more extensive and encompass those molecular formulas not presently represented by any known sources. The relatively broad distributions of $\mathrm{H} / \mathrm{C}$ and $\mathrm{O} / \mathrm{C}$ molar ratios for compounds in these samples (Fig. 3a, b) further illustrate the complex nature of aerosol WSOC, however, certain patterns emerge.

The majority of S-containing molecular formulas identified in both samples had $\mathrm{H} / \mathrm{C}$ values greater than 1.2 and simultaneously showed high $\mathrm{O} / \mathrm{C}$ ratios. Organosulfur compounds have been detected in previous aerosol WSOC studies (Romero and Oehme, 2005; Gilardoni et al., 2007). Romero and Oehme (2005) further observed $\mathrm{HSO}_{4}^{-}$mass fragments in high molecular weight (HMW) atmospheric HULIS and postulated that these anions were covalently bound by sulfonation or sulfation processes. The high O/C
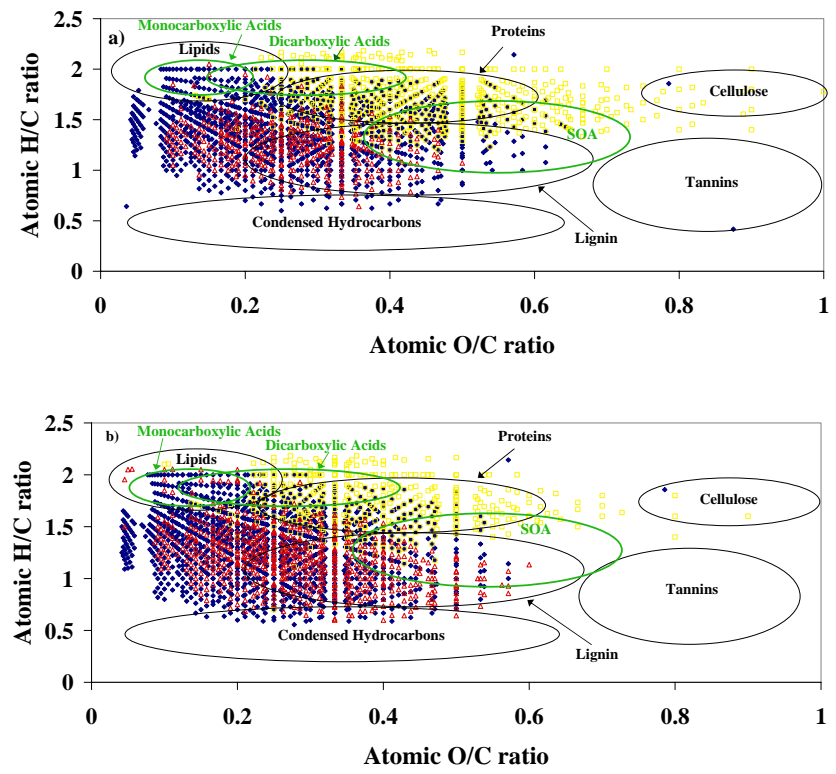

Fig. 3. van Krevelen plots for molecular formulas assigned to FTICR mass spectra peaks in aerosol WSOC samples from a) New York and b) Virginia. Blue diamonds represent compounds containing only $\mathrm{C}, \mathrm{H}$, and $\mathrm{O}$, yellow squares represent S-containing compounds, and red triangles are $\mathrm{N}$-containing compounds. Black ovals represent traditional potential source molecular classes (after Sleighter et al., 2007). The green SOA oval represents published molar $\mathrm{H} / \mathrm{C}$ and $\mathrm{O} / \mathrm{C}$ ratios from laboratory investigations of secondary organic aerosols (Reinhardt et al., 2007; Altieri et al., 2008). $\mathrm{O} / \mathrm{C}$ ratios for the green ovals representing mono- and dicarboxylic acids were calculated for molecules containing 10-30 carbons, and the $\mathrm{H} / \mathrm{C}$ ratios for these ovals assumed little branching and few double bonds.

ratios of many S-containing molecular formulas observed in the New York and Virginia aerosol WSOC samples (Fig. 3a, b) are also consistent with covalently bound $\mathrm{HSO}_{4}^{-}$. Elevated $\mathrm{H} / \mathrm{C}$ molar ratios $(>1.5)$ are indicative of saturated hydrocarbons with few double bonds, and the high $\mathrm{H} / \mathrm{C}$ ratios in $\mathrm{S}$ containing compounds in these samples indicate that any sulfonation or sulfation processes resulted in mostly saturated compounds. S-containing aromatic compounds that would show much lower $\mathrm{H} / \mathrm{C}$ ratios are not evident in these samples. In contrast, N-containing and C-H-O compounds (Fig. 3a, b) frequently have $\mathrm{H} / \mathrm{C}$ values $<1$ and do not typically have $\mathrm{O} / \mathrm{C}$ values $>0.6$, suggesting that the nitrogenous WSOC compounds in these samples tended to be highly carbonaceous, condensed compounds. Previous laboratory studies of SOAs have also reported the formation of nitro-aromatic compounds from the photooxidation of aromatic compounds in the presence of $\mathrm{NO}_{\mathrm{x}}$ (Forstner et al., 1997; Jang and Kamens, 2001; Alfarra et al., 2006). The data presented here are thus consistent with the presence of nitro-aromatic compounds as well. 

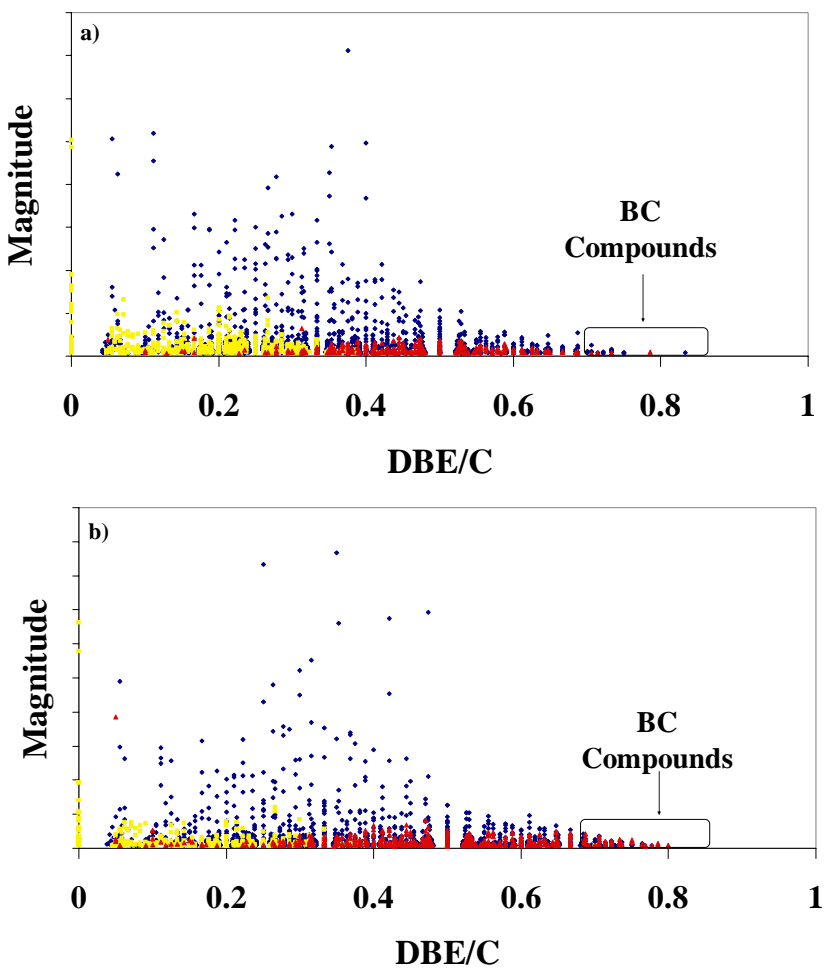

Fig. 4. Peak magnitude vs. DBE/C for molecular formulas identified in aerosol WSOC samples from (a) New York and (b) Virginia. Blue diamonds represent compounds containing only $\mathrm{C}, \mathrm{H}$, and $\mathrm{O}$, yellow squares represent $\mathrm{S}$-containing compounds, and red triangles are $\mathrm{N}$-containing compounds. For both samples, the $\mathrm{y}$-axis was compressed to make lower magnitude compounds visible. Several high magnitude $\mathrm{C}, \mathrm{H}, \mathrm{O}$ compounds at DBE/C between 0.3 and 0.5 are off scale.

\subsection{Black carbon in aerosol-derived WSOC}

The aerosol WSOC samples from New York and Virginia contained several peaks representing molecular formulas with $\mathrm{DBE} / \mathrm{C}$ values greater than 0.7 , a characteristic of condensed aromatic ring structures and a cut-off value proposed for the identification of BC molecular formulas (Fig. 4; Hockaday et al., 2006). BC defined in this manner made up only $4 \%$ and $1 \%$ of the identified molecular formulas in Virginia and New York aerosol WSOC, respectively, and were present at small magnitudes relative to the majority of other molecular formulas present (Fig. 4a, b). When peak magnitudes were accounted for as in Table 2 above, BC molecular formulas accounted for only $1.5 \%$ (Virginia) and $0.3 \%$ (New York) of the total peak magnitudes. BC was also a minor component of the total aerosol OC though BC/OC was higher in the New York sample (0.050; Table 1) compared with the Virginia sample (0.018; Table 1). The higher BC/OC ratio in the New York sample relative to the Virginia sample did not translate to a higher contribution of $\mathrm{BC}$ identified in the
WSOC mass spectra indicating that the $\mathrm{BC}$ component of the Virginia aerosol sample was relatively more soluble than the $\mathrm{BC}$ in the New York sample. BC has traditionally been studied in particulate OM (e.g. Mitra et al., 2002; Gatari and Bowman, 2003; Dickens et al., 2004). However, BC may attain greater hydrophilic character in the course of its oxidation (Kamegawa et al., 2002; Park et al., 2005; Zuberi et al., 2005), and several studies of aqueous OM mixtures have identified a BC component (Mannino and Harvey, 2004; Kim et al., 2004; Kramer et al., 2004; Hockaday et al., 2006). A recent FT-ICR MS study of freshwater DOM identified BC using molar $\mathrm{H} / \mathrm{C}$ and $\mathrm{O} / \mathrm{C}$ ratios using a similar approach to the one employed in the present study but did not report the number of peaks characterized as BC (Kim et al., 2004). A study of BC in DOM from the Delaware Bay found that $9 \%$ of bay DOC and 4-7\% of coastal ocean DOC was BC (Mannino and Harvey, 2004). The authors listed sediment resuspension and atmospheric transport from nearby Philadelphia, $\mathrm{PA}$ as likely sources of $\mathrm{BC}$ to the bay. We are unaware of aerosol WSOC studies that have quantified BC, but soot oxidation has been demonstrated to form WSOC compounds (Decesari et al., 2002).

As noted previously, the CTO-375 BC method employed on the bulk aerosol material is a highly selective method that detects only highly condensed soot-BC. Masiello (2004) speculated that in contrast to the CTO-375 method, ultrahigh resolution mass spectrometry may be able to detect the full range of $\mathrm{BC}$ materials. Therefore, the relative scarcity of peaks assigned BC molecular formulas in the current study using this more comprehensive technique does not support a strong aerosol WSOC source for BC to riverine and coastal DOC. However, the small amounts of BC in WSOC from both of these rural sites suggest that areas having stronger $\mathrm{BC}$ sources such as urban regions may contribute greater amounts of $\mathrm{BC}$ to riverine and coastal DOC.

Radiocarbon analysis of the New York aerosol WSOC from August 2006 showed a mean $\Delta^{14} \mathrm{C}$ signature of $-230 \%$ o $(n=3)$ corresponding to a radiocarbon age of $\sim 2050$ years bp. These values have been found to be representative of other aerosol WSOC $\Delta^{14} \mathrm{C}$ samples measured over time at both the NY and VA sites (Wozniak, unpublished data). A simple two-source isotopic mass balance assuming one source devoid of ${ }^{14} \mathrm{C}$ (e.g. fossil fuels) and another source having present-day levels of ${ }^{14} \mathrm{C}$ (e.g. modern living biomass) suggests that more than $20 \%$ of the New York WSOC comes from a fossil source. While the radiocarbon analyses were not performed on the New York sample analyzed for ESI FT-ICR MS, two of the samples analyzed for radiocarbon content were collected during the same sampling period as the sample analyzed by ESI FT-ICR MS, and the third was collected just two days later. As a result, there is reason to believe that the $\Delta^{14} \mathrm{C}$ signature of the WSOC sample collected for ESI FT-ICR MS analysis would be similar to this $-230 \%$ value. The samples analyzed for radiocarbon signatures were not, however, $\mathrm{C}_{18}$-extracted to remove 
Table 3. Molecular formulas of compounds consistent with proposed or identified SOA compounds from selected previous studies. Relative peak magnitudes are ranked from 1 (strongest peak assigned a molecular formula in spectrum) to $\mathrm{n}$ (weakest peak assigned a molecular formula in spectrum; for VA, $n=2098$; for NY, $n=2261$ ).

\begin{tabular}{|c|c|c|c|c|}
\hline \multirow[t]{2}{*}{ Elemental Formula } & \multirow[t]{2}{*}{$\mathrm{m} / \mathrm{z}$ of Ion } & \multicolumn{2}{|c|}{ Relative Peak Magnitude } & \multirow[t]{2}{*}{ Proposed Formation Mechanism } \\
\hline & & VA & NY & \\
\hline $\mathrm{C}_{11} \mathrm{H}_{18} \mathrm{O}_{6}$ & 245.1031 & 1924 & not present & Dimer product of 1-methyl cyclohexene ozonolysis ${ }^{a}$ \\
\hline $\mathrm{C}_{17} \mathrm{H}_{26} \mathrm{O}_{5}$ & 309.1708 & 40 & 53 & Dimer product of $\beta$-pinene ozonolysis ${ }^{b}$ \\
\hline $\mathrm{C}_{17} \mathrm{H}_{26} \mathrm{O}_{6}$ & 325.1657 & 45 & 106 & Dimer product of $\beta$-pinene ozonolysis $b$ \\
\hline $\mathrm{C}_{18} \mathrm{H}_{28} \mathrm{O}_{4}$ & 307.1915 & 11 & 28 & Dimer product of $\beta$-pinene ozonolysis ${ }^{b}$ \\
\hline $\mathrm{C}_{18} \mathrm{H}_{28} \mathrm{O}_{6}$ & 339.1813 & 42 & 49 & Dimer product of $\beta$-pinene ozonolysis ${ }^{b}$ \\
\hline $\mathrm{C}_{18} \mathrm{H}_{28} \mathrm{O}_{7}$ & 355.1762 & 115 & 203 & Dimer product of $\beta$-pinene ozonolysis $b$ \\
\hline $\mathrm{C}_{18} \mathrm{H}_{30} \mathrm{O}_{7}$ & 357.1919 & 155 & 307 & Dimer product of $\alpha$-pinene ozonolysis ${ }^{a}$ \\
\hline $\mathrm{C}_{19} \mathrm{H}_{30} \mathrm{O}_{7}$ & 369.1919 & 119 & 143 & Dimer product of $\beta$-pinene ozonolysis $b$ \\
\hline $\mathrm{C}_{19} \mathrm{H}_{32} \mathrm{O}_{6}$ & 355.2126 & 95 & 103 & Dimer product of $\beta$-pinene ozonolysis $b$ \\
\hline $\mathrm{C}_{20} \mathrm{H}_{32} \mathrm{O}_{4}$ & 335.2228 & 36 & 7 & Dimer product of $\alpha$-pinene ozonolysis ${ }^{c}$ \\
\hline $\mathrm{C}_{20} \mathrm{H}_{32} \mathrm{O}_{5}$ & 351.2177 & 68 & 19 & Dimer product of $\alpha$-pinene ozonolysis ${ }^{c}$ \\
\hline $\mathrm{C}_{19} \mathrm{H}_{30} \mathrm{O}_{5}$ & 337.2021 & 32 & 16 & Dimer product of $\alpha$-pinene ozonolysis ${ }^{c}$ \\
\hline $\mathrm{C}_{18} \mathrm{H}_{28} \mathrm{O}_{5}$ & 323.1864 & 26 & 22 & Dimer product of $\alpha$-pinene ozonolysis ${ }^{c}$ \\
\hline
\end{tabular}

salts as the sample analyzed for ESI FT-ICR MS was. As a result, the radiocarbon analyses were performed on the total WSOC, while the $\mathrm{C}_{18}$-extracted sample likely represents about half of the WSOC (Louchouarn et al., 2000; Kim et al., 2003a). Nonetheless, it is reasonable to assume that the $\mathrm{C}_{18}$-extracted sample contains a considerable fraction of the fossil-derived component of the WSOC.

$\mathrm{BC}$ emitted as a byproduct of fossil fuel combustion represents a logical potential source of the aged WSOC as suggested by the radiocarbon analyses. The radiocarbon data indicate that more than $20 \%$ of the New York aerosol WSOC could be derived from fossil sources. However, the FT-ICR MS data suggest that BC molecular formulas account for only $0.3 \%$ of the peak magnitudes in the entire mass spectra for the New York sample and do not support a significant input of BC to aerosol WSOC. Therefore, other sources of aged organic matter, both natural and anthropogenic, must be responsible for the aged WSOC (e.g. aged soil organic matter, SOAs from gaseous fossil fuel combustion precursors, etc.). In addition, several of the identified $\mathrm{BC}$ compounds contain $\mathrm{N}$ in their molecular formulas, and as discussed previously, $\mathrm{C}_{18}$ extraction does not typically retain organic $\mathrm{N}$ compounds efficiently (Benner, 2002; Koch et al., 2005). Therefore, BCderived compounds present in the initial WSOC sample may not be quantitatively represented to the same extent as non$\mathrm{N}$ containing compounds in the FT-ICR mass spectra. Alternately, $\mathrm{DBE} / \mathrm{C} \geq 0.7$ may be too conservative as a cut-off for a complete identification of BC compounds (Fig. 4a, b; Hockaday et al., 2006).

While BC comprises only a small portion of identified molecular formulas in the aerosol WSOC samples analyzed here, their identification nonetheless highlights another application of ESI FT-ICR MS. BC is generally defined as carbonaceous material thought to be composed of a highly refractory, slow-cycling pool of compounds resulting from combustion processes and can be a significant portion of aerosol carbonaceous material (e.g. Novakov et al., 2005; and references therein). In a biogeochemical context, the identification of $\mathrm{BC}$ in aerosol WSOC suggests that variable amounts of $\mathrm{BC}$ may become desorbed into rainwater and transported through watersheds to various aquatic systems. To this point, BC has primarily been studied using one of several operational definitions that do not measure the full spectrum of BC (Masiello 2004; Hammes et al., 2007). The use of ESI FT-ICR MS to identify BC in aerosols may therefore provide molecular level information allowing for better characterization of BC in WSOC.

4.6 Potential contributions of secondary organic aerosols to aerosol-derived WSOC

Formula assignments for many of the FT-ICR MS peaks in this study were consistent with formulas proposed in experimental laboratory investigations of SOA formation by other researchers (Table 3). While molecular structure can not be deduced from the data collected in the present study, the molecular formulas are consistent with the presence of at least certain SOA compounds or their isomers and illustrate how the extremely high mass resolution of FT-ICR MS may be utilized to identify common SOA species in fieldcollected aerosols, aerosol-WSOC, rainwater and other natural aqueous samples. 
Of the molecular formulas in Table $3, \mathrm{C}_{18} \mathrm{H}_{28} \mathrm{O}_{4}$ was the potential SOA species with the largest peak magnitude in the Virginia sample, while $\mathrm{C}_{20} \mathrm{H}_{32} \mathrm{O}_{4}$ had the largest peak magnitude for potential SOA species in the New York sample. Heaton et al. (2007) observed $\mathrm{C}_{18} \mathrm{H}_{28} \mathrm{O}_{4}$ as a product of $\beta$ pinene ozonolysis and suggested its formation is via reaction of a monomer end product and a hydroperoxide intermediate of $\beta$-pinene ozonolysis. In comparison, $\mathrm{C}_{20} \mathrm{H}_{32} \mathrm{O}_{4}$ (Table 3) was a product of $\alpha$-pinene ozonolysis, and its presence was attributed to dimerization of pinonaldehyde, a known product of primary ozonolysis, via either aldol condensation or gem-diol formation (Tolocka et al., 2004).

The majority of previous experimental and field studies identifying SOA compounds focused on low molecular weight (LMW) species $(\mathrm{m} / \mathrm{z}<200$; e.g. Forstner et al., 1997; Jang and Kamens, 2001). However, recent experimental work also argues for the formation of HMW SOA compounds that are oligomers of precursor compounds (Gao et al., 2004; Kalberer et al., 2004; Tolocka et al., 2004; Dommen et al., 2006; Heaton et al., 2007). The abundance of HMW peaks in the mass spectra (Fig. 1a, b) and molecular formula assignments in Table 3 agree with these recent studies on the contribution of HMW compounds to SOA (Gao et al., 2004; Kalberer et al., 2004; Tolocka et al., 2004; Dommen et al., 2006; Heaton et al., 2007). While the ESI FTICR MS method utilized in this study does not characterize LMW SOA products, detailed molecular characterization of HMW SOA using FT-ICR MS is possible. This approach may help establish which of the many HMW SOA compounds identified in experimental laboratory investigations are prevalent in field samples, thus assisting in the identification of common formation processes and pathways under natural environmental conditions. Laboratory studies have also employed ESI FT-ICR MS to examine the behavior of $\alpha$-pinene in the presence of ozone to reveal that polymerization processes were important in the formation of HMW SOA (Tolocka et al., 2004; Reinhardt et al., 2007). Tolocka et al. (2004) also found several species whose presence could not be explained by monomer polymerization or degradation and proposed unknown complex chemical pathways for their formation. This study also reported SOA oligomers from a field sample illustrating the utility of FT-ICR MS in validating laboratory investigations (Tolocka et al., 2004). ESI FTICR MS may alternately be used in field and laboratory investigations to detect SOA compounds that may be abundant but previously unidentified.

\section{Conclusions}

ESI FT-ICR MS is well-adapted to molecularly characterizing aerosol WSOC as a result of its extremely high mass resolving power and ability to ionize and detect polar, hydrophilic molecules such as the HULIS-type molecules in WSOC. van Krevelen diagrams of molecular formulas found in aerosol WSOC may be further utilized for understanding the general compositional features of WSOC compounds. Finally, ESI FT-ICR MS may be particularly well-suited to providing investigators with an inventory of $\mathrm{BC}$ and SOA molecular formulas in aerosol WSOC that may permit more detailed study of these highly complex substances for better understanding their formation, transformational, and degradation pathways. While further work is required to make ESI FT-ICR MS analyses more quantitative or semi-quantitative, the method has been demonstrated here to be an excellent and promising qualitative tool available to the atmospheric chemistry community for detailed characterization of the water soluble components of aerosols.

Acknowledgements. The lead author (ASW) was partially supported by a Graduate Fellowship from the Hudson River Foundation during the course of this study. Additional funding for this work came from the following NSF awards to JEB: DEB Ecosystems grant DEB-0234533, Chemical Oceanography grant OCE-0327423, and Integrated Carbon Cycle Research Program grant EAR-0403949. We thank J. Paul Rinehimer and Pat Dickhudt for writing a MATLAB script to pre-process the molecular formula data, Willy Reay for field assistance in Virginia, Jon Cole, Heather Malcom, and Vicky Kelly for field assistance in New York, Ed Keesee for laboratory assistance, and Susan Hatcher for assistance at the COSMIC facility. This manuscript is contribution \#2917 to the Virginia Institute of Marine Science.

Edited by: A. Pszenny

\section{References}

Alfarra, M. R., Paulsen, D., Gysel, M., Garforth, A. A., Dommen, J., Prevot, A. S. H., Worsnop, D. R., Baltensperger, U., and Coe, H.: A mass spectrometric study of secondary organic aerosols formed from the photooxidation of anthropogenic and biogenic precursors in a reaction chamber, Atmos. Chem. Phys., 6, 52795293, 2006,

http://www.atmos-chem-phys.net/6/5279/2006/.

Altieri, K. E., Seitzinger, S. P., Carlton, A. G., Turpin, B. J., Klein, G. C., and Marshall, A. G.: Oligomers formed through in-cloud methylglyoxal reactions: Chemical composition, properties, and mechanisms investigated by ultra-high resolution FT-ICR mass spectrometry, Atmos. Environ., 42, 1476-1490, 2008.

Baker, A. R., Jickells, T. D., Witt, M., and Linge, K. L.: Trends in the solubility of iron, aluminum, manganese and phosphorous in aerosol collected over the Atlantic Ocean, Mar. Chem., 98, 4358, 2006.

Benner, R.: Chemical composition and reactivity, in: D.A. Hansell and C.A. Carlson, Editors, Biogeochemistry of Marine Dissolved Organic Matter, Academic Press, New York, 59-90, 2002.

Bond, T. C., Streets, D. G., Yarber, K. F., Nelson, S. M., Woo, J.-H., and Klimont, Z.: A technology-based global inventory of black and organic carbon emissions from combustion, J. Geophys. Res.-Atm., 109, D14203, doi:10.1029/2003JD003697, 2004.

Brown, T. L. and Rice, J. A.: Effect of experimental parameters on the ESI FT-ICR mass spectrum of fulvic acid, Anal. Chem., 72(2), 384-390, 2000. 
Charlson, R. J.: Atmospheric visibility related to aerosol mass concentration: A review, Environ. Sci. Technol., 3, 913-918, 1969.

Chen, L.-W. A., Doddridge, B. G., Dickerson, R. R., Chow, J. C., and Henry, R. C.: Origins of fine aerosol mass in the BaltimoreWashington corridor: implications from observation, factor analysis, and ensemble air parcel back trajectories, Atmos. Environ., 36, 4541-4554, 2002.

Davidson, C. I., Phalen, R. F., and Solomon, P. A.: Airborne particulate matter and human health: A review, Aerosol Sci. Tech., 39, 737-749, 2005.

Decesari, S., Facchini, M. C., Fuzzi, S., and Tagliavini, E.: Characterization of water-soluble organic compounds in atmospheric aerosol: A new approach, J. Geophys. Res.-Atm., 105(D1), 1481-1489, doi:10.1029/1999JD900950, 2000.

Decesari, S., Facchini, M. C., Matta, E., Mircea, M., Fuzzi, S., Chughtai, A. R., ands Smith, D. M.: Water soluble organic compounds formed by oxidation of soot, Atmos. Environ., 36, 1827 1832, 2002.

Decesari, S., Mircea, M., Cavalli, F., Fuzzi, S., Moretti, F., Tagliavini, E., and Facchini, M. C.: Source attribution of watersoluble organic aerosol by nuclear magnetic resonance spectroscopy, Environ. Sci. Technol., 41, 2479-2484, 2007.

Dickens, A. F., Gelinas, Y., and Hedges, J. I.: Physical Separation of combustion and rock sources of graphitic black carbon in sediments, Mar. Chem., 92, 215-224, 2004.

Dickhut, R. M., Canuel, E. A., Gustafson, K. E., Liu, K., Arzayus, K. M., Walker, S. E., Edgecombe, G., Gaylor, M. O., and Macdonald, E. H.: Automotive sources of carcinogenic polycyclic aromatic hydrocarbons associated with particulate matter in the Chesapeake Bay region, Environ. Sci. Technol., 34, 4635-4640, 2000.

Dommen, J., Metzger, A., Duplissy, J., Kalberer, M., Alfarra, M. R., Gascho, A., Weingartner, E., Prevot, A. S. H., Verheggen, B., and Baltensperger, U.: Laboratory observation of oligomers in the aerosol from isoprene/ $\mathrm{NO}_{\mathrm{x}}$ photooxidation, Geophys. Res. Lett., 33, L13805, doi:10.1029/2006GL026523, 2006.

Driscoll, C. T., Lawrence, G. B., Bulger, A. J., Butler, T. J., Cronan, C. S., Eagar, C., Lambert, K. F., Likens, G. E., Stoddard, J. L., and Weathers, K. C.: Acidic deposition in the northeastern United States: Sources and inputs, ecosystem effects, and management strategies, Bioscience, 51, 180-198, 2001.

Duarte, R. M. B. O., Pio, C. A., and Duarte, A. C.: Spectroscopic study of the water-soluble organic matter isolated from atmospheric aerosols collected under different atmospheric conditions, Anal. Chim. Acta, 530, 7-14, 2005.

Edney, E. O., Kleindienst, T. E., Conver, T. S., McIver, C. D., Corse, E. W., and Weathers, W. S.: Polar organic oxygenates in $\mathrm{PM}_{2.5}$ at a southeastern site in the United States, Atmos. Environ., 37, 3947-3965, 2003.

Elmquist, M., Cornelissen, G., Kukulska, Z., and Gustafsson, O.: Distinct oxidative stabilities of char versus soot black carbon: Implications for quantification and environmental recalcitrance, Global Biogeochem. Cy., 20, GB2009, doi:10.1029/2005GB002629, 2006.

Forstner, H. J., Flagan, R. C., and Seinfeld, J. H.: Secondary organic aerosol from the photooxidation of aromatic hydrocarbons: Molecular composition, Environ. Sci. Technol., 31, 1345-1358, 1997.
Fuzzi, S., Decesari, S., Facchini, M. C., Matta, E., Mircea, M., and Tagliavini, E.: A simplified model of the water soluble organic component of atmospheric aerosols, Geophys. Res. Lett., 20, 4079-4082, 2001.

Galiulin, R. V., Bashkin, V. N., and Galiulina, R. A.: Review: Behavior of persistent organic pollutants in the air-plant-soil system, Water Air Soil Poll., 137, 179-191, 2002.

Gao, S., Ng, N. L., Keywood, M., Varutbangkul, V., Bahreini, R., Nenes, A., He, J., Yoo, K. Y., Beauchamp, J. L., Hodyss, R. P., Flagan, R. C., and Seinfeld, J. H.: Particle phase acidity and oligomer formation in secondary organic aerosol, Environ. Sci. Technol., 38, 6582-6589, 2004.

Gatari, M. J. and Boman, J.: Black carbon and total carbon measurements at urban and rural sites in Kenya, East Africa, Atmos. Environ., 37, 1149-1154, 2003.

Gaskell, S. J.: Electrospray: principles and practice, J. Mass Spectrom., 32(7), 677-688, 1997.

Gilardoni, S., Russell, L. M., Sorooshian, A., Flagan, R. C., Seinfeld, J. H., Bates, T. S., Quinn, P. K., Allan, J. D., Williams, B., Goldstein, A. H., Onasch, T. B., and Worsnop, D. R.: Regional variation of organic functional groups in aerosol particles on four U. S. east coast platforms during the International Consortium for Atmospheric Research on Transport and Transformation 2004 campaign, J. Geophys. Res.-Atm., 112, D10S27, doi:10.1029/2006JD007737, 2007.

Grannas, A. M., Hockaday, W. C., Hatcher, P. G., Thompson, L. G., and Mosley-Thompson, E.: New revelations on the nature of organic matter in ice cores, J. Geophys. Res., 111, D04304, doi:10.1029/2005JD006251, 2006.

Grimshaw, H. J. and Dolske, D. A.: Rainfall concentrations and wet atmospheric deposition of phosphorous and other constituents in Florida, U. S. A., Water Air Soil Poll., 137, 117-140, 2002.

Gustafsson, O., Haghseta, F., Chan., C., Macfarlane, J., and Gschwend, P. M.: Quantificationof the dilute sedimentary soot phase: implications for PAH speciation and bioavailability, Environ. Sci. Technol., 31, 203-209, 1997.

Hammes, K., Schmidt, M. W. I., Smernik, R. J., Currie, L. A., Ball, W. P., Nguyen, T. N., Louchouarn, P., Houel, S., Gustafsson, O., Elmquist, M., Cornelissen, G., Skjemstad, J. O., Masiello, C. A., Song, J., Peng. P., Mitra, S., Dunn, J. C., Hatcher, P. G., Hockaday, W. C., Smith, D. M., Hartkopf-Froder, C., Bohmer, A., Luer, B., Huebert, B. J., Armelung, W., Brodowski, S., Huang, L., Zhang, W., Gschwend, P. M., Flores-Cervantes, D. X., Largeau, C., Rouzaud, J.-N., Rumpel, C., Guggenberger, G., Kaiser, K., Rodionov, A., Gonzalez-Vila, F. J., Gonzalez-Perez, J. A., de la Rosa, J. M., Manning, D. A. C., Lopez-Capel, E., and Ding, L.: Comparison of quantification methods to measure fire-derived (black/elemental) carbon in soils and sediments using reference materials from soil, water, sediment and the atmosphere, Global Biogeochem. Cy., 21, GB3016, doi:10.1029/2006GB002914, 2007.

Heaton, K. J., Dreyfus, M. A., Wang, S., and Johnston, M. V.: Oligomers in the early stage of biogenic secondary organic aerosol, Environ. Sci. Technol., 41, 6129-6136, 2007.

Highwood, E. J. and Kinnersley, R. P.: When smoke gets in our eyes: The multiple impacts of atmospheric black carbon in climate, air quality and health, Environ. Int., 32, 560-566, 2006. 
Hockaday, W. C., Grannas, A. M., Kim, S., and Hatcher, P. G.: Direct molecular evidence for the degradation and mobility of black carbon in soils from the ultrahigh-resolution mass spectral analysis of dissolved organic matter from a fire-impacted forest soil, Org. Geochem., 37, 501-510, 2006.

Jacobson, M. C., Hansson, H.-C., Noone, K. J., and Charlson, R. J.: Organic atmospheric aerosols: Review and state of the science, Rev. Geophys., 38(2), 267-294, 2000.

Jang, M. and Kamens, R. M.: Characterization of secondary aerosol from the photooxidation of toluene in the presence of $\mathrm{NO}_{\mathrm{x}}$ and 1-propene, Environ. Sci. Technol., 35, 3626-3639, 2001.

Jaoui, M., Klendienst, T. E., Lewandowski, M., Offenberg, J. H., and Edney, E. O.: Identification and quantification of aerosol polar oxygenated compounds bearing carboxylic or hydroxyl groups. 2. Organic tracer compounds from monoterpenes, Environ. Sci. Technol., 39, 5661-5673, 2005.

Jurado, E., Jaward, F. M., Lohmann, R., Jones, K. C., Simo, R., and Dachs, J.: Atmospheric dry deposition of persistent organic pollutants to the Atlantic and inferences for the global oceans, Environ. Sci. Pollut. R., 38, 5505-5513, 2004.

Kalberer, M., Paulsen, D., Sax, M., Steinbacher, M., Dommen, J., Prevot, A. S. H., Fisseha, R., Weingartner, E., Frankevich, V., Zenobi, R., and Baltensperger, U.: Identification of polymers as major components of atmospheric organic aerosols, Science, 303, 1659-1662, 2004.

Kamegawa, K., Nishikubo, K., Kodama, M., Adachi, Y., and Yoshida, H.: Oxidative degradation of carbon blacks with nitric acid II. Formation of water-soluble polynuclear aromatic compounds, Carbon, 40, 1447-1455, 2002.

Kanakidou, M., Seinfeld, J. H., Pandis, S. N., Barnes, I., Dentener, F. J., Facchini, M. C., Van Dingenen, R., Erven, B., Nenes, A., Nielsen, C. J., Swietlicki, E., Putaud, J. P., Balkanski, Y., Fuzzi, S., Horth, J., Moortgat, G. K., Winterhalter, R., Myhre, C. E. L., Tsigaridis, K., Vignati, E., Stephanou, E. G., and Wilson, J.: Organic aerosol and global climate modeling: a review, Atmos. Chem. Phys., 5, 1053-1123, 2005, http://www.atmos-chem-phys.net/5/1053/2005/.

Kim, S., Simpson, A.J., Kujawinski, E.B., Freitas, M.A., and Hatcher, P.G.: High resolution electrospray ionization mass spectrometry and 2D solution NMR for the analysis of DOM extracted by C18 solid phase disk, Org. Geochem., 34(9), 13251335, 2003a.

Kim, S., Kramer, R. W., and Hatcher, P. G.: Graphical method for analysis of ultrahigh-resolution broadband mass spectra of natural organic matter, the van Krevelen diagram, Anal. Chem., 75(20), 5336-5344, 2003b.

Kim, S., Kaplan, L. A., Benner, R., and Hatcher, P. G.: Hydrogendeficient molecules in natural riverine water samples-evidence for the existence of black carbon in DOM, Mar. Chem., 92, 225234, 2004.

Kleefeld, S., Hoffer, A., Krivacsy, Z., and Jennings, S. G.: Importance of organic and black carbon in atmospheric aerosols at Mace Head, on the West Coast of Ireland (53 $19^{\prime} \mathrm{N}, 9^{\circ} 54^{\prime} \mathrm{W}$ ), Atmos. Environ., 36, 4479-4490, 2002.

Koch, B. P., Witt, M., Engbrodt, R., Dittmar, T., and Kattner, G.: Molecular formulae of marine and terrigenous dissolved organic matter detected by electrospray ionization Fourier transform ion cyclotron resonance mass spectrometry, Geochim. Cosmochim. Act., 69, 3299-3308, 2005.
Koch, D.: Transport and direct radiative forcing of carbonaceous and sulfate aerosols in the GISS GCM, J. Geophys. Res.-Atm., 106, D17, 20311-20322, 2001.

Kramer, R. W., Kujawinski, E. B., and Hatcher, P. G.: Identification of black carbon derived structures in a volcanic ash soil humic acid by Fourier transform ion cyclotron resonance mass spectrometry, Environ. Sci. Technol., 38, 3387-3395, 2004.

Krivacsy, Z., Hoffer, A., Sarvari, Z., Temesi, D., Baltensperger, U., Nyeki, S., Weingartner, E., Kleefeld, S., and Jennings, S. G.: Role of organic and black carbon in the chemical composition of atmospheric aerosol at European background sites, Atmos. Environ., 35, 6231-6244, 2001.

Kujawinski, E. B.: Electrospray ionization Fourier transform ion cyclotron resonance mass spectrometry (ESI FT-ICR MS): Characterization of complex environmental mixtures, Environ. Forensics, 3, 207-216, 2002.

Kujawinski, E. B. and Behn, M. D.: Automated analysis of electrospray ionization Fourier transform ion cyclotron resonance mass spectra of natural organic matter, Anal. Chem., 78, 4363-4373, 2006.

Kujawinski, E. B., Freitas, M. A., Zang, X., Hatcher, P. G., GreenChurch, K. B., and Jones, R. B.: The application of electrospray ionization mass spectrometry (ESI MS) to the structural characterization of natural organic matter, Org. Geochem., 33, 171180, 2002a.

Kujawinski E. B., Hatcher P. G., and Freitas M. A.: High-resolution Fourier transform ion cyclotron resonance mass spectrometry of humic and fulvic acids: improvements and comparisons, Anal. Chem., 74, 413-419, 2002b.

Kujawinski, E. B., del Vecchio, R., Blough, N. V., Klein, G. C., and Marshall, A. G.: Probing molecular-level transformations of dissolved organic matter: insights on photochemical degradation and protozoan modification of DOM from electrospray ionization Fourier transform ion cyclotron resonance mass spectrometry, Mar. Chem., 92, 23-37, 2004.

Likens, G. E. and Bormann, F. H.: Acid rain: A serious regional environmental problem, Science, 184, 1176-1179, 1974.

Liu, W., Wang, Y., Russell, A., and Edgerton, E. S.: Atmospheric aerosol over two urban-rural pairs in the southeastern United States: Chemical composition and possible sources, Atmos. Environ., 39, 4453-4470, 2005.

Lohmann, U. and Feichter, J.: Global indirect aerosol effects: a review, Atmos. Chem. Phys., 5, 715-737, 2005, http://www.atmos-chem-phys.net/5/715/2005/.

Louchouarn, P., Opsahl, S., and Benner, R.: Isolation and quantification of dissolved lignin from natural waters using solid-phase extraction and GC/MS, Anal. Chem., 72, 2780-2787, 2000.

Mannino, A. and Harvey, H. R.: Black carbon in estuarine and coastal ocean dissolved organic matter, Limnol. Oceanogr., 49, 735-740, 2004.

Marshall, A. G., Hendrickson, C. L., and Jackson, G. S.: Fourier transform ion cyclotron resonance mass spectrometry: a primer, Mass Spectrom. Rev., 17, 1-35, 1998.

Masiello, C. A.: New directions in black carbon organic geochemistry, Mar. Chem., 92, 201-213, 2004. 
Mayol-Bracero, O. L., Guyon, P., Graham, B., Roberts, G., Andreae, M. O., Decesari, S., Facchini, M. C., Fuzzi, S., and Artaxo, P.: Water-soluble organic compounds in biomass burning aerosols over Amazonia 2. Apportionment of the chemical composition and importance of the polyacidic fraction, J. Geophys. Res.-Atm., 107, D20, 8091, doi:10.1029/2001JD000522, 2002.

McIntyre, C. and McRae, C.: Proposed guidelines for sample preparation and ESI-MS analysis of humic substances to avoid self-esterification, Org. Geochem. 36, 543-553, 2005.

Mitra, S., Bianchi, T. S., McKee, B. A., and Sutula, M.: Black carbon from the Mississippi River: Quantitites, sources, and potential implications for the global carbon cycle: Environ. Sci. Technol., 36, 2296-2302, 2002.

Novakov, T., Menon, S., Kirchstetter, T. W., Koch, D., and Hansen, J. E.: Aerosol organic carbon to black carbon ratios: Analysis of published data and implications for climate forcing, J. Geophys. Res.-Atm., 110, D21205, doi:10.1029/2005JD005977, 2005.

Park, R. J., Jacob, D. J., Palmer, P. I., Clarke, A. D., and Weber, R. J.; Zondlo, M. A.; Eisele, F. L.; Bandy, A. R.; Thornton, D. C.; Sachse, G. W.; Bond, T. C.: Export efficiency of black carbon aerosol in continental outflow: Global implications, J. Geophys. Res.-Atm., 110, D11205, 2005.

Penner, J. E., Eddleman, H., and Novakov, T.: Towards the development of a global inventory of black carbon emissions, Atmos. Environ., 27A, 1277-1295, 1993.

Ramanathan, V., Crutzen, P. J., Kiehl, J. T., and Rosenfeld, D.: Aerosols, climate, and the hydrological cycle, Science, 294, 2119-2124, 2001.

Raymond, P. A. and Bauer J. E.: Use of ${ }^{14} \mathrm{C}$ and ${ }^{13} \mathrm{C}$ natural abundances as a tool for evaluating freshwater, estuarine and coastal organic matter sources and cycling. Org. Geochem., 32, 469485, 2001.

Reinhardt, A., Emmenegger, C., Gerrits, B., Panse, C., Dommen, J., Baltensperger, U., Zenobi, R., Kalberer, M.: Ultrahigh mass resolution and accurate mass measurements as a tool to characterize oligomers in secondary organic aerosols, Anal. Chem., 79, 4074-4082, 2007.

Romero, F. and Oehme, M.: Organosulfates - A new component of humic-like substances in atmospheric aerosols?, J. Atmos. Chem., 52, 283-294, 2005.

Rostad C. E. and Leenheer J. A.: Factors that affect molecular weight distribution of Suwannee river fulvic acid as determined by electrospray ionization/mass spectrometry, Anal. Chim. Acta, 523, 269-278, 2004.

Sannigrahi, P., Sullivan, A. P., Weber, R. J., and Ingall, E. D.: Characterization of water-soluble organic carbon in urban atmospheric aerosols using solid state ${ }^{13} \mathrm{C}$ NMR spectroscopy, Environ. Sci. Technol., 40, 666-672, 2006.

Satheesh, S. K. and Moorthy, K. K.: Radiative effects of natural aerosols: A review, Atmos. Environ., 39, 2089-2110, 2005.

Saxena, P. and Hildemann, L. M.: Water-soluble organics in atmospheric particles: A critical review of the literature and application of thermodynamics to identify candidate compounds, J. Atmos. Chem., 24, 57-109, 1996.

Sleighter, R. L. and Hatcher, P. G.: The application of electrospray ionization coupled to ultrahigh resolution mass spectrometry for the molecular characterization of natural organic matter, J. Mass Spectrom., 42, 559-574, 2007.
Sleighter, R. L. and Hatcher, P. G.: Molecular characterization of dissolved organic matter (DOM) along a river to ocean transect of the lower Chesapeake Bay by ultrahigh resolution electrospray ionization Fourier transform ion cyclotron resonance mass spectrometry, Mar. Chem., 110, 140-152, 2008.

Sleighter, R. L., McKee, G. A., Liu, Z., and Hatcher, P. G.: Naturally present fatty acids as internal calibrants for Fourier transform mass spectra of dissolved organic matter, Limnol. Oceanogr.-Meth., 6, 246-253, 2008.

Stenson, A. C., Landing, W. M., Marshall, A. G., and Cooper, W. T.: Ionization and fragmentation of humic substances in electrospray ionization Fourier transform-ion cyclotron resonance mass spectrometry, Anal. Chem., 74, 4397-4409, 2002.

Stenson, A. C., Marshall, A. G., and Cooper, W. T.: Exact masses and chemical formulas of individual Suwannee River fulvic acids from ultrahigh resolution electrospray ionization Fourier transform ion cyclotron resonance mass spectra, Anal. Chem., 75, 1275-1284, 2003.

Sullivan, A. P. and Weber, R. J.: Chemical characterization of the ambient organic aerosol soluble in water: 2. Isolation of acid, neutral, and basic fractions by modified sizeexclusion chromatography, J. Geophys. Res.-Atm., 111, D05315, doi:10.1029/2005JD006486, 2006.

Tanner, R. L., Parkhurst, W. J., and McNichol, A. P.: Fossil sources of ambient aerosol carbon based on ${ }^{14} \mathrm{C}$ measurements, Aerosol Sci. Tech., 38 (S1), 133-139, 2004.

Tolocka, M. P., Jang, M., Ginter, J. M., Cox, F. J., Kamens, R. M., and Johnston, M. V.: Formation of oligomers in secondary organic aerosol, Environ. Sci. Technol., 38, 1428-1434, 2004.

Toon, O. B.: How pollution suppresses rain, Science, 287, 17631765, 2000.

Tremblay, L. B., Dittmar, T., Marshall, A. G., Cooper, W. J., and Cooper, W. T.: Molecular characterization of dissolved organic matter in a North Brazilian mangrove porewater and mangrovefringed estuaries by ultrahigh resolution Fourier transform-ion cyclotron resonance mass spectrometry and excitation/emission spectroscopy, Mar. Chem., 105, 15-29, 2007.

Wang, H., Kawamura, K., and Shooter, D.: Wintertime organic aerosols in Christchurch and Auckland, New Zealand: contributions of residential wood and coal burning and petroleum utilization, Environ. Sci. Technol., 40, 5257-5262, 2006.

Wolff, G. T., Kelly, N. A., Ferman, M. A., Ruthkosky, M. S., Stroup, D. P., and Korsog, P. E.: Measurements of sulfur oxides, nitrogen oxides, haze and fine particles at a rural site on the Atlantic Coast, JAPCA J. Air Waste Ma., 36, 585-591, 1986.

Yang, H., Xu, J., Wu, W.-S., Wan, C. H., and Yu, J. Z.: Chemical characteristics of water-soluble organic aerosols at Jeju Island collected during ACE-Asia, Environ. Chem., 1, 13-17, 2004.

Yu, L. E., Shulman, M. L., Kopperud, R., and Hildemann, L. M.: Characterizations of organic compounds collected during southeastern aerosol and visibility study: water-soluble organic species, Environ. Sci. Technol., 39, 707-715, 2005.

Zencak, Z., Elmquist, M., nad Gustafsson, O.: Quantification and radiocarbon source apportionment of black carbon in atmospheric aerosols using the CTO-375 method, Atmos. Envir., 41, 7895-7906, 2007.

Zuberi, B., Johnson, K. S., Aleks, G. K., Molina, L. T., and Molina, M. J.: Hydrophilic properties of aged soot, Geophys. Res. Lett., 32, L01807, doi:10.1029/2004GL021496, 2005. 